\title{
Insectivores (Mammalia) from the earliest Oligocene (MP 21) of Belgium
}

\section{R. Smith}

Laekenveld 6, B-1780 Wemmel, Belgium. E-mail: richardsmithpal@hotmail.com

Manuscript received: February 2004; accepted: August 2004

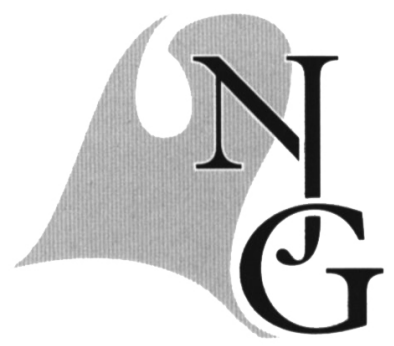

\begin{abstract}
Insectivore remains are not common in the Lower Oligocene of Europe. For this reason, the study of the earliest Oligocene insectivore fauna (MP 21) from Boutersem and Hoogbutsel, all together yielding nine species, representing five families, constitutes an important progress in the knowledge of the Late Eocene and Early Oligocene insectivore evolution. Some of the genera discovered in Belgium are known from upper Eocene sites (Saturninia, Amphidozotherium, Euronyctia, Eotalpa), whereas others are not known before the Oligocene (Butselia, Tetracus, Heterosoricinae ind.). The co-occurrence of primitive species of Nyctitheriidae with modern forms belonging to the Plesiosoricidae, Talpidae and Erinaceidae at the EoceneOligocene boundary suggests a transition fauna. Between the Priabonian (Late Eocene) and the Rupelian (Early Oligocene), the endemic European insectivores were in competition with the new immigrants. This faunal turnover is generally accepted as the 'Grande Coupure' event (the MP 21 event).
\end{abstract}

Keywords: Belgium, insectivores, Lower Oligocene, Mammalia

\section{Introduction}

Three localities yielded terrestrial vertebrates in the Lower Oligocene from Belgium: Hoogbutsel (Glibert \& de Heinzelin de Braucourt, 1952), Hoeleden (Glibert \& de Heinzelin de Braucourt, 1954) and Boutersem TGV (Fig. 1). The Hoogbutsel and Hoeleden localities are known since half a century. Fifteen papers were written on both localities (Smith, 2003). The third locality was discovered on a temporary exposure of lowermost Oligocene (Early Rupelian) during the HST railway construction in 1999 and yielded abundant vertebrate remains of fishes, amphibian, reptiles (turtles, lizards, snakes, crocodiles), birds (Mayr \& Smith, 2001) and mammals. The preliminary study of the mammal remains revealed the presence of at least 22 taxa including the following families: Didelphidae (Marsupialia); Nyctitheriidae, Plesiosoricidae, Soricidae
(Soricomorpha); Erinaceidae (Erinaceomorpha); Vespertilionidae (Chiroptera); Theridomyidae, Gliridae, Cricetidae, Eomyidae (Rodentia). The record consists mainly of isolated teeth and a few jaw fragments. The vertebrate beds occur at the base of a fluvio-lacustrine complex, known as the Boutersem Member, which belongs to the Borgloon Formation (Tongeren Group, previously known and mapped as upper 'continental' Tongrian Tg2).

The importance of the three localities lies with the many vertebrate taxa they yielded from the oldest continental levels of the Lower Oligocene near the 'Grande Coupure' (Stehlin, 1909). The faunas of these levels are correlated with the reference level MP 21 of the mammalian biochronological scale for the European Paleogene (Schmidt-Kittler, 1987; Aguilar et al., 1997) defined on the fauna of Soumailles (Aquitaine Basin, France). 


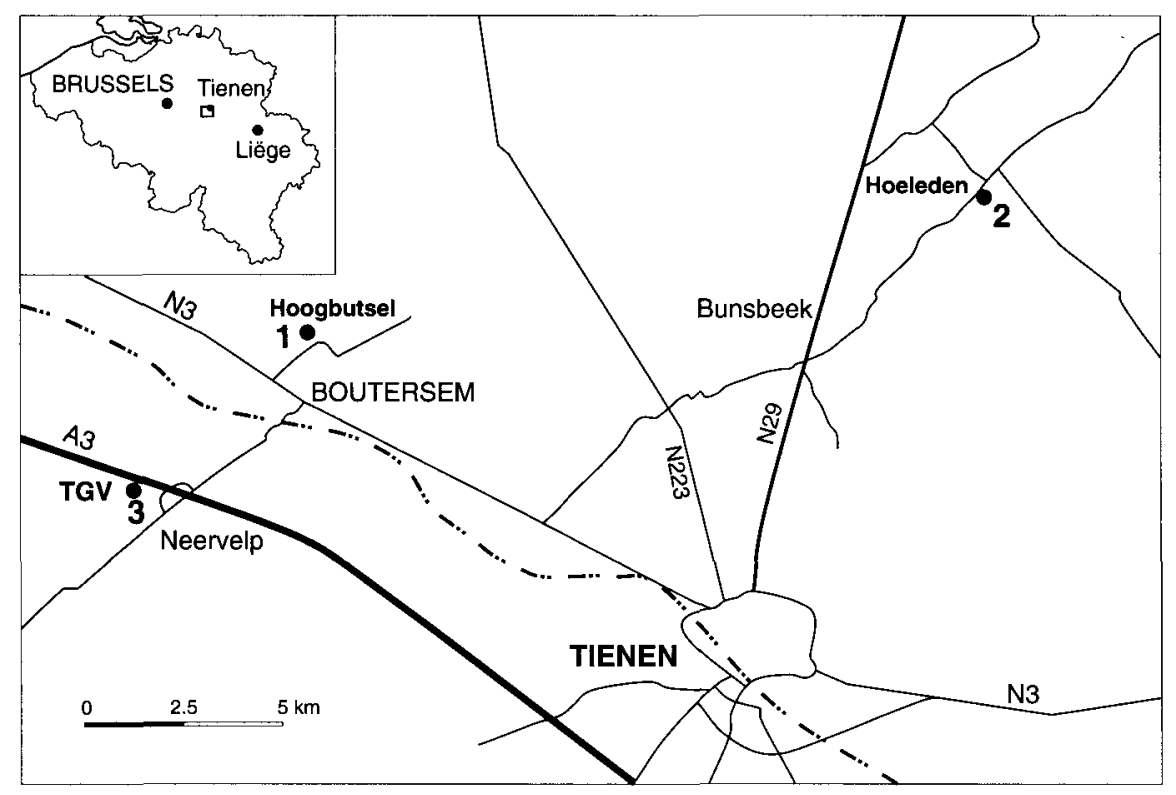

Fig. 1. Location of the localities from the earliest Oligocene (MP 21) of Belgium. 1. Hoogbutsel; 2. Hoeleden; 3. Boutersem TGV.
With the exception of Butselia biveri described by Quinet \& Misonne (1965), no insectivore was previously published from the Lower Oligocene of Belgium. Full descriptions of the forms introduced here will follow elsewhere.

\section{Methods and materials}

The fossils discovered at Hoogbutsel are housed in the Royal Belgian Institute of Natural Sciences (IRSNB). The specimens from Boutersem TGV are in the collection of the author. No insectivore teeth recorded from the Hoeleden locality are present in the IRSNB collection. The new insectivore material in this paper comes from the locality Boutersem TGV, only the teeth of Tetracus nanus (Aymard, 1846) are recorded from Hoogbutsel.

The mammal systematic classification used here is that proposed by McKenna \& Bell (1997). The terminology used for dental crests and cusps is based on that defined by Van Valen (1966).

The new discoveries in the lower Oligocene from Belgium

In Belgium, the erinaceid Tetracus nanus (Pl. 1, Fig. 9) is only known from Hoogbutsel. A few teeth are present in the IRSNB collection. $M 1 /$, and $M / 1-M / 3$ were recognised. Compared to the $M 1 /$ from the Oligocene locality of Garouillas (Quercy, MP 25) described by Crochet (1995, fig. 6), the Belgian M1/ seems to be somewhat larger labio-lingually, the cusps somewhat weaker and the labial edge more oblique. Based on only one specimen it is not possible to decide whether the differences result from intraspecific variation or these characters have a specific significance. The lower teeth from Hoogbutsel are similar in morphology to those of the French localities. Tetracus nanus is known from MP 21 to MP 26 (Crochet, 1995).

The family Talpidae (Pl. 1, Fig. 6) is up to day only present in Boutersem TGV. Sixteen isolated teeth of Eotalpa n. sp. are recorded. This new species is recognised on the basis of $\mathrm{P} 4 / \mathrm{M} 1 / \mathrm{M} 2 /, \mathrm{M} / 1, \mathrm{M} / 2, \mathrm{M} / 3$. Sigé et al. (1977) previously described the genus Eotalpa represented by the monospecific taxa Eotalpa anglica from the Lower Headon Beds of the Wight Island, London Basin.

The plesiosoricid Butselia biveri (P1. 1, Fig. 7) was described by Quinet $\&$ Misonne (1965) on the basis of five isolated teeth from Hoogbutsel. The new material from Boutersem TGV is composed by one mandible fragment with $P / 4-M / 1$, one maxilla fragment with $\mathrm{P} 3 /-\mathrm{P} 4 /$ and 32 isolated teeth. The following positions have been identified: DP4/, P3/-M3/, P/4-M/3. The species is characterized by a reduced $\mathrm{P} 3 /$. The semimolariform $\mathrm{P} 4 /$ is as wide as the $\mathrm{Ml}$ /, with a considerable development of the metastylar lobe and a very long postmetacrista labio-posteriorly orientated. M1/-M3/ and M/1-M/3 are gradually smaller. M1/ has a preparacrista and a postmetacrista labially orientated and shows two very strong stylocone and D cusps; the stylar shelf is very large; the postcingulum is broad; the conules are absent on all the upper cheek teeth. DP4/, M1/ and M2/ have precingulum and postcingulum with small hypocone. On the lower molars, the trigonid is very strong; the talonid is low; the cusps of the talonid are weak. B. biveri has only been recovered from MP 21 in a few localities from Europe.

The nyctithere Saturninia gracilis Stehlin, 1940 (Pl. 1, Fig. 4) is represented by one left mandible with $P / 3-$ 


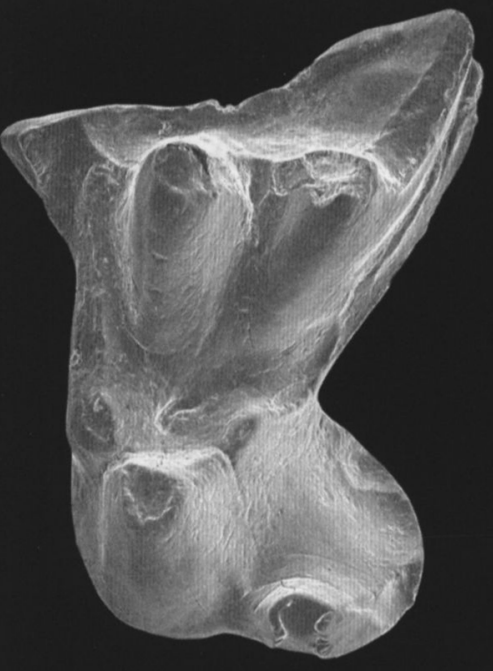

1

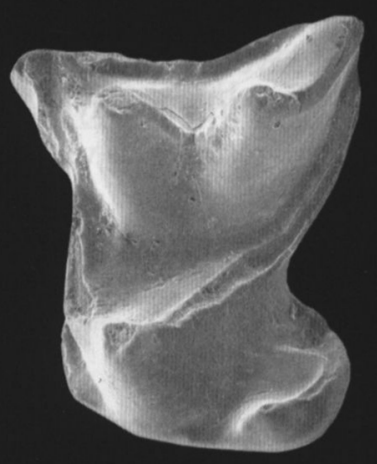

4

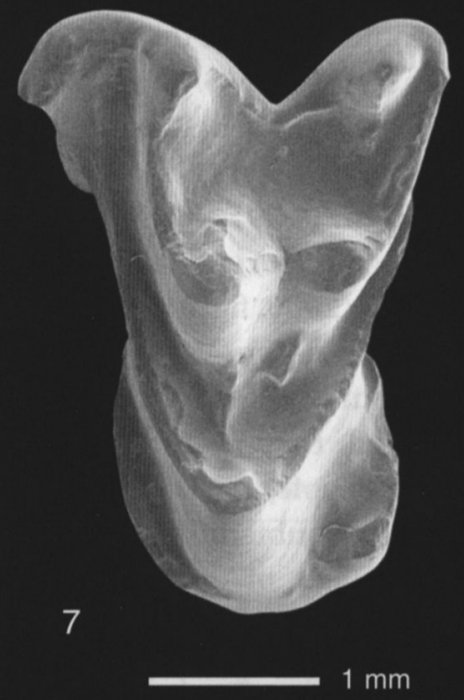

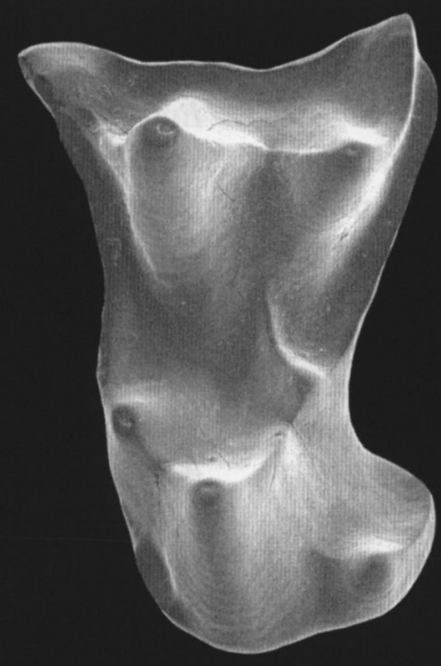

2
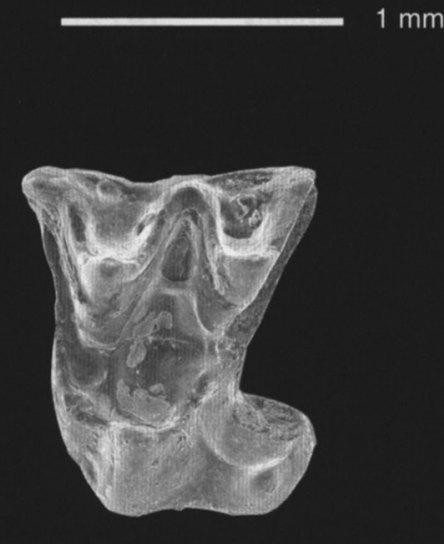

5

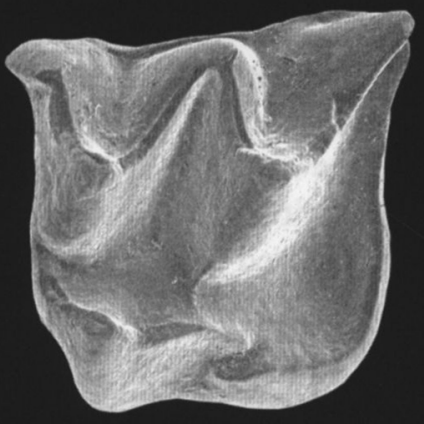

8

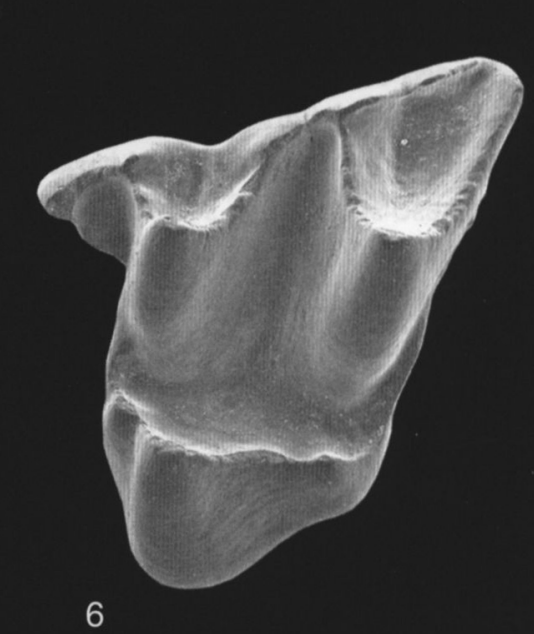

6

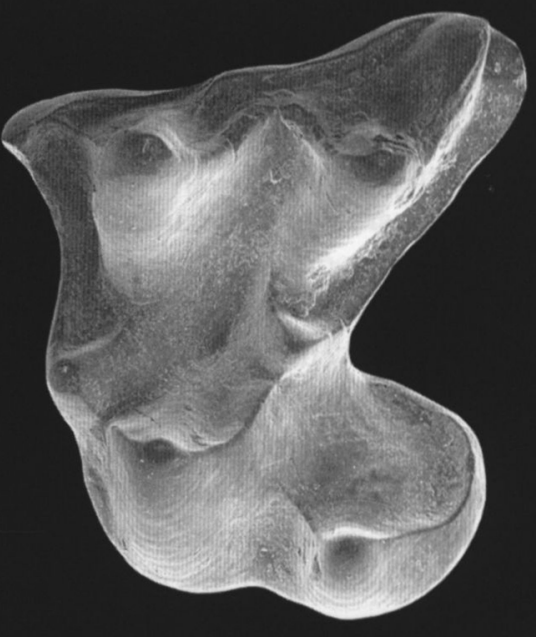

3

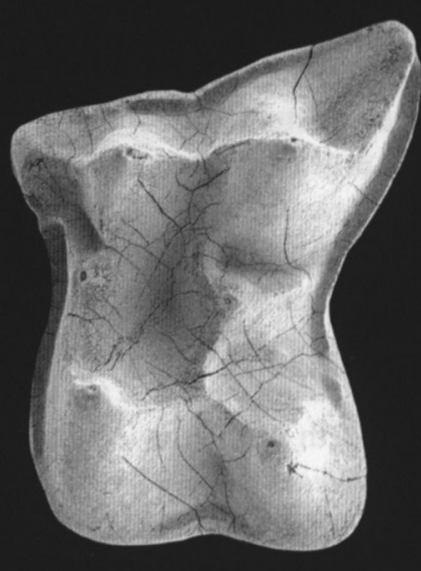

9

$1 \mathrm{~mm}$

Plate 1. Fig. 1. Amphidozotherium cayluxi Filhol, 1876; Fig. 2. cf. Saturninia n. sp.; Fig. 3. Euronyctia n. sp.; Fig. 4. Saturninia gracilis Stehlin, 1940; Fig. 5. cf. Euronyctia n. sp.; Fig. 6. Eotalpa n. sp.; Fig. 7. Butselia biveri Quinet \& Misonne, 1965; Fig. 8. Heterosoricinae ind.; Fig. 9. Tetracus nanus Aymard, 1846. All Ml/ in occlusal view. Locality: all from Boutersem TGV, except Fig. 9 from Hoogbutsel. Scale bars are $1 \mathrm{~mm}$. 
$M / 3$, three other mandible fragments with teeth, and 27 isolated teeth. The specimens from the Lower Oligocene of Belgium show some differences from those of the types of the Priabonian locality of GösgenKanal (MP 18, Canton Soleure, Switzerland) and from La Débruge (France) (Stehlin, 1940). The teeth are somewhat smaller. The upper molars bear a larger talon, and the precingulum is shorter and more prominent. The lower teeth are shorter and narrower with more slender cusps. The antero-labial cingulum is longer and extended below the protoconid.

S. gracilis has been recorded from MP 16 until MP 21 (Sigé, 1976), but this genus represents different lineages and causes a taxonomical problem. The comparison of the Belgian specimens with those of Stehlin's collection housed at the Naturhistorisches Museum from Basel shows that there is a mixing of two different taxa in the specimens from La Débruge. Some specimens really belong to $S$. gracilis but some others must be attributed to the genus Euronyctia (R. Smith, pers. obs.). Sigé (1976) figured different specimens of lower teeth to show the morphological variability of $S$. gracilis. Among these specimens some are to be attributed to another taxon (Euronyctia?): figs. 7c, e, f, g, 9d. The diagnosis of the genus gracilis, G.C. 879 (Sigé, 1976) do not bear an ascendant oblique crest until the apex of the metaconid as it is the case in Euronyctia. Many other species assigned later to the genus Saturninia bear an ascendant oblique crest and have probably to be assigned to another genus. Therefore the genus Saturninia has probably a shorter extension than thought to-day (Table 2).

Five mandible fragments with teeth and 59 isolated teeth are referred to cf. Saturninia n. sp. (Pl. 1, Fig. 2). It is a medium-large size nyctithere. The metacone of $\mathrm{P} 4 /$ is reduced. The upper molars are short, labiolingually elongated, with a medium developed talon. Both $\mathrm{M} 1 /$ and $\mathrm{M} 2 /$ have a well-developed precingulum and hypocone. $M / 3$ and $M 3 /$ are not reduced. The lower teeth show an oblique crest that ascends on the distal wall of the metaconid.

Euronyctia n. sp. (PI. 1, Fig. 3) is represented by two mandibles bearing each $\mathrm{P} / 4$ and $\mathrm{M} / 2$, and 34 isolated teeth. The teeth of the new species are close in size to those of E. tobieni (Sigé, 1976). Both upper and lower cheek teeth show an important dilambdodonty. There is a mesostyle and a little precingulum on the upper molars. P4/, M1/, M2/ have a broad rounded talon with a medium-sized hypocone. Postcingulid and anterolabial cingulid are well developed. On the lower molars the prominent oblique crest reaches the apex of the metaconid. A notch is present in the oblique crest at one third of the height. The postero-lingual border of the talonid on $M / 1$ and $M / 2$ forms an angle of about $90^{\circ}$. There are clear morphological differences between $E$. tobieni and the new species (Smith, in prep.).

Seventeen isolated teeth are attributed to cf. Euronyctia n. sp. (Pl. 1, Fig. 5). It is a very small species. The molars are very dilambdodont. The postparacrista and premetacrista are connected to a strong mesostyle. The paraconule is protruded as the metaconule and the premetaconule crista is strong. There is a little precingulum on both $\mathrm{M} 1 /, \mathrm{M} 2 /$. The well-developed talon bears a small but well-distinct hypocone. On the lower molars, the hypoconulid and the entoconid are close together. The hypoconulid is projected posteriorly from the talonid. The angle between the lingual and the posterior borders of $M / 1$ and $M / 2$ is at least $130^{\circ}$ at the level of the entoconid.

There is a taxonomical problem between the genera Euronyctia Sigé, 1997 and Paradoxonycteris Revilliod, 1922. Sigé (1997) described the taxon Euronyctia montana $\mathrm{n}$. gen, n. sp. He included Saturninia grisollensis and $S$. tobieni in this new genus. Hooker \& Weidmann (2000) recombined Euronyctia tobieni (Sigé, 1976) with Paradoxonycteris and gave an emended diagnosis for this genus. Unfortunately, the holotype and only specimen of Paradoxonycteris soricodon is very damaged and most of the diagnostic characters are not visible on this specimen. The emended diagnose is thus more based on specimens belonging to $E$. tobieni and other Euronyctia species. In this situation, it should be preferable to consider Paradoxonycteris soricodon as a nomen nudum (dubium?) and to keep Euronyctia for the species grisollensis, tobieni and montana.

Amphidozotherium cayluxi Filhol, 1876 (P1. 1, Fig. 1) is represented by a left mandible with $M / 2-M / 3$ and 46 isolated teeth. On P4/-M2/ from Boutersem TGV the hypocone is more prominent as on the teeth recovered from the Quercy. It lacks on M3/. The ratio length/ width is different on $\mathrm{M} 1$ / from Belgium and France. The lower teeth are very similar to those figured and described by Sige (1976, fig. 95-96) from the Upper Eocene of the Quercy (France) and with those figured by Hooker \& Weidmann $(2000$, fig. 41$)$ from the Upper Eocene of Mormont (Canton Vaud, Switzerland). A. cayluxi is known from MP 19 to MP 21 .

One $\mathrm{M} 1 /$ is referred to an unknown genus of Heterosoricinae Viret \& Zapfe, 1951 (Pl. 1, Fig. 8). The only known genus of the subfamily Heterosoricinae, in Europe, from the age of Boutersem TGV is Quercysorex Engesser, 1975. Up to day, three species of this genus are described: Qu. primaevus (Filhol, 1882) from Lamandine in Quercy (old collections), Qu. herrlingensis (Palmowski \& Wachendorf, 1966) from Herrlingen 1 (MP 22) and Qu. ulmensis Ziegler, 1998 from Herrlingen 8-9 (MP 28). The two first species are only based on lower jaws and teeth 
(Engesser, 1975). With some lower jaws, Ziegler (1998) described and figured a M2/ of Quercysorex ulmensis. Differences in size and morphology are observable between the upper molars of $Q u$. ulmensis and the specimen from Boutersem TGV. It is clearly impossible to determine this specimen more precisely at the moment.

\section{Discussion}

The insectivore faunas of Hoogbutsel and Boutersem TGV show some differences (Table 1). Among the most significant differences between both faunas are: the presence of Tetracus nanus, a representative of the family Erinaceidae at Hoogbutsel, and the presence of the family Talpidae at Boutersem. Comparison of the avian faunas between these two sites leads to a similar situation (Mayr \& Smith, 2001, 2002). The differences in the faunal composition are probably due to palaeoecological reasons.

Table 1. Insectivore species from MP 21 level from Belgium, recorded in both localities Hoogbutsel and Boutersem TGV.

\begin{tabular}{|c|c|c|}
\hline Taxon & Hoogbutsel & Boutersem TGV \\
\hline Tetracus nanus Aymard, 1846 & + & \\
\hline \multicolumn{3}{|l|}{ Butselia biveri Quinet \& } \\
\hline Misonne, 1965 & + & + \\
\hline Saturninia gracilis Stehlin, 1940 & + & + \\
\hline Saturninia n. sp. & + & + \\
\hline Euronyctia n. sp. & + & + \\
\hline cf. Euronyctia n. sp. & + & + \\
\hline \multicolumn{3}{|l|}{ Amphidozotherium cayluxi } \\
\hline Filhol, 1876 & + & + \\
\hline Heterosoricinae ind. & + & + \\
\hline Eotalpa n. sp. & & + \\
\hline
\end{tabular}

Table 2 is based on several publications (Crochet, 1995; Sigé, 1976; Sigé, 1997; Sigé et al., 1977; Leduc, 1996; Ziegler, 1998) and personal observations of the author. Except for the genus Saturninia, Table 2 shows the level MP 21 is a limit between two different insectivore faunas. The first one, with the genus Euronyctia, Eotalpa, Amphidozotherium, Saturninia is the oldest fauna living in Europe during the Upper Eocene. The second one, with the genus Tetracus and Heterosoricinae ind. is the fauna of the new immigrants. As discussed before, Saturninia probably includes different genera and therefore needs a revision. With a new genus name, a part of the taxa presently known as 'Saturninia' will also be ranged as new immigrants.

\section{Conclusion}

Paleogene insectivores are rare throughout Europe but the Belgian Lower-Oligocene localities (MP 21) yielded many remains of insectivores. On the nine taxa discovered in Belgium two are recorded before MP 21 (Saturninia gracilis and Amphidozotherium cayluxi) and two others after MP 21 (Tetracus nanus and Heterosoricinae ind. sp.). But none is known at the same time before and after MP 21. Nevertheless Tetracus nanus was recorded in Coyrou 1-2 (Quercy, France) in an intermediate level between MP 20 and MP 21 (Legendre et al., 1995). If we only consider the genera (Table 2) four taxa are recorded before MP 21 and two are known after MP 21. This situation could be explained by the fact that few insectivores were recovered from the Quercy sites, which yielded most of the mammal material from this age. But it could also be explained by the fact that MP 21 is just the moment of a faunal turnover. The endemic European insectivores were at the same moment in competition with the new immigrants. This hypothesis comes close to what was suggested by Legendre et al. (1995) and must be confirmed by the study of a more complete mammal assemblage. The different new taxa notes herein will be named and described soon by the author in separate papers.

Table 2. Distribution of the insectivore genera recorded in the Lower Oligocene from Belgium in European localities from MP 16 to MP 26.

\begin{tabular}{|c|c|c|c|c|c|c|c|c|c|c|c|}
\hline Taxon & MP16 & MP17 & MP18 & MP19 & MP20 & MP21 & MP22 & MP23 & MP24 & MP25 & MP26 \\
\hline Euronyctia & + & + & + & & + & + & & & & & \\
\hline Eotalpa & & & + & & & + & & & & & \\
\hline Amphidozotherium & & & & + & + & + & & & & & \\
\hline Butselia & & & & & & + & & & & & \\
\hline Saturninia & + & + & + & + & + & + & + & + & + & + & + \\
\hline Tetracus & & & & & & + & + & + & + & + & + \\
\hline Heterosoricinae ind. & & & & & & + & $?$ & $?$ & $?$ & $?$ & $?$ \\
\hline
\end{tabular}




\section{Acknowledgments}

I would like to thank Burkart Engesser (Naturhistorisches Museum, Basel, Switzerland), Bernard Sigé (Université Claude-Bernard, Lyon 1, France) and Jean-Yves Crochet (Université de Montpellier II, France) for the access to the collections in their care and helpful discussions concerning Oligocene insectivores; Lars van den Hoek Ostende (National Museum of Natural History, Naturalis, Leiden) for constructive comments in reviewing the manuscript; Geert Dewaele and Hugo Van Laer (HST construction company) for giving authorization and technical assistance in the Boutersem site; from the IRSNB: Jacques Herman and Piet Laga for introducing me to this locality; Pierre Hoffman for help in the field; Julien Cilis for the SEM photographs and Thierry Smith for consultation and useful discussion. This study is a part of a project on the Eocene-Oligocene transition in Belgium funded by the Fonds voor Wetenschappelijk Onderzoek (Fund for Scientific Research) Vlaanderen (research project $\mathrm{n}^{\circ} \mathrm{G} .0093 .01$ ).

\section{References}

Aguilar, J. P. et al. (106 authors), 1997. Synthèses et tableaux de corrélations / Syntheses and correlation tables. In: Aguilar, J.-P., Legendre, S. \& Michaux, J. (eds), Actes du Congrès BiochroM'97. Mémoires et Travaux de l'Institut de Montpellier, Ecole Pratique des Hautes Etudes, Sciences de la Vie et de la Terre 21: 769-805.

Crochet, J.-Y., 1995. Le Garouillas et les sites contemporains (Oligocène, MP 25) des Phosphorites du Quercy (Lot, Tarn-etGaronne, France) et leurs faunes de vertébrés. 4. Marsupiaux et Insectivores. Palaeontographica Abt. A 236: 39-75.

Engesser, B., 1975. Revision der europäischen Heterosoricinae (Insectivora, Mammalia). Eclogae Geologicae Helvetiae 68: 649-671.

Glibert, M. \& de Heinzelin de Braucourt, J., 1952. Le gîte des vertébrés tongriens de Hoogbutsel. Bulletin de l'Institut royal des Sciences naturelles de Belgique, Sciences de la Terre 28(52): $1-22$.

Glibert, M. \& de Heinzelin de Braucourt, J., 1954. Le gîte des vertébrés tongriens de Hoeleden. Bulletin de l'Institut royal des Sciences naturelles de Belgique, Sciences de la Terre 30(1): 1-14.

Hooker, J.J. \& Weidmann, M., 2000. The Eocene mammal faunas of Mormont, Switzerland. Schweizerische Paläontologische Abhandlungen 120: $143 \mathrm{pp}$.
Leduc, P., 1996. Caractéristiques évolutives des faunes de mammifères d'Europe occidentale et d'Amérique du Nord au Paléogène. Thèse présentée pour obtenir le grade de Docteur de l'Université Paris 6. Université Pierre et Marie Curie: 453 pp.

Legendre, S., Marandat, B., Rémy, J. A., Sigé, B., Sudre, J., VianeyLiaud, M., Crochet, J.-Y., Godinot, M., 1995. Coyrou 1-2, une nouvelle faune de mammifères des phosphorites du Quercy, niveau intermédiaire (MP 20-21) proche de la 'Grande Coupure'. Géologie de la France 1: 63-68.

Mayr, G. \& Smith, R., 2001. Ducks, rails and limicoline waders (Aves: Anseriformes, Gruiformes, Charadrifformes) from the lowermost Oligocene of Belgium. Geobios 34: 547-561.

Mayr, G. \& Smith, R., 2002. Avian remains from the lowermost Oligocene of Hoogbutsel (Belgium). Bulletin de l'Institut royal des Sciences naturelles de Belgique, Sciences de la Terre 72 : 139-150.

McKenna, M. C. \& Bell, S. K., 1997. Classification of Mammals Above the Species Level. Columbia University Press (New York): $631 \mathrm{pp}$.

Schmidt-Kittler, N., (ed) 1987. International Symposium on Mammalian Biostratigraphy and Paleoecology of the European Paleogene; Mainz, 1987. Münchner Geowissenschaftliche Abhandlungen, (A) 10: 1-32.

Sigé, B., 1976. Insectivores primitifs de l'Eocène supérieur et Oligocène inférieur d'Europe occidentale. Nyctithériidés. Mémoires du Muséum national d'Histoire naturelle, Série C, Sciences de la Terre 34: 140 pp.

Sigé, B., 1997. Les mammifères insectivores des nouvelles collections de Sossís et sites associés (Eocène supérieur, Espagne). Geobios 30: 91-113.

Sigé, B., Crochet, J.-Y. \& Insole, A.N., 1977. Les plus vieilles taupes. Geobios. Mémoire Spécial 1: 141-157.

Smith, R, 2003. Les vertébrés terrestres de l'Oligocène inférieur de Belgique (Formation de Borgloon, MP 21): inventaire et interprétation des données actuelles. Coloquios de Paleontologia. Volumen Extraordinario 1: 647-657.

Stehlin, H.-G., 1909. Remarques sur les faunules de mammifères des couches éocènes et oligocènes du Bassin de Paris. Bulletin de la Société Géologique de France (4) 9: 488-520.

Stehlin, H.-G., 1940. Zur Stammesgeschichte des Soriciden. Eclogae Geologicae Helvetiae 33: 298-306.

Van Valen, L. M., 1966. Deltatheridia, a new order of Mammals. Bulletin of the American Museum of Natural History 132 (1): 1-126.

Ziegler, R., 1998. Marsupialia und Insectivora (Mammalia) aus den oberoligozänen Spaltenfüllungen Herrlingen 8 und Herrlingen 9 bei Ulm (Baden-Württemberg). Senckenbergiana lethaea $77:$ 101-143. 